\title{
WGS and RNA Studies Diagnose Noncoding DMD Variants in Males With High Creatine Kinase
}

Leigh B. Waddell, PhD, Samantha J. Bryen, BSc (Hons), Beryl B. Cummings, PhD, Adam Bournazos, BSc (Hons), Frances J. Evesson, PhD, Himanshu Joshi, B Software Engineering, B Business (Finance), Jamie L. Marshall, PhD, Taru Tukiainen, PhD, Elise Valkanas, BA (Biology), Ben Weisburd, BS (Computer Sc), Simon Sadedin, PhD, Mark R. Davis, PhD, Fathimath Faiz, PhD, Rebecca Gooding, PhD, Sarah A. Sandaradura, MBChB, FRACP, PhD, Gina L. O'Grady, MBChB, FRACP, PhD, Michel C. Tchan, MBBS, FRACP, PhD, David R. Mowat, MBBS, FRACP, Emily C. Oates, MBBS, FRACP, PhD, Michelle A. Farrar, MBBS, FRACP, PhD,

Hugo Sampaio, MBBCh, FRACP, MPhil, Alan Ma, MBBS, FRACP, Katherine Neas, MBChB, FRACP, Min-Xia Wang, PhD, Amanda Charlton, MBChB, FRCPA, Charles Chan, MBBS (Hons), FRCPA, PhD, Diane N. Kenwright, MBBS, FRCPA, Nicole Graf, MBBS, FRCPA, Susan Arbuckle, MBBS, FRCPA, Nigel F. Clarke, MBChB, FRACP, PhD,* Daniel G. MacArthur, PhD, Kristi J. Jones, MBBS, FRACP, PhD, Monkol Lek, PhD, and Sandra T. Cooper, PhD

Neurol Genet 2021;7:e554. doi:10.1212/NXG.0000000000000554

\section{Abstract}

\section{Objective}

To describe the diagnostic utility of whole-genome sequencing and RNA studies in boys with suspected dystrophinopathy, for whom multiplex ligation-dependent probe amplification and exomic parallel sequencing failed to yield a genetic diagnosis, and to use remnant normal DMD splicing in 3 families to define critical levels of wild-type dystrophin bridging clinical spectrums of Duchenne to myalgia.

\section{Methods}

Exome, genome, and/or muscle RNA sequencing was performed for 7 males with elevated creatine kinase. PCR of muscle-derived complementary DNA (cDNA) studied consequences for $D M D$ premessenger RNA (pre-mRNA) splicing. Quantitative Western blot was used to determine levels of dystrophin, relative to control muscle.

\section{Results}

Splice-altering intronic single nucleotide variants or structural rearrangements in $D M D$ were identified in all 7 families. Four individuals, with abnormal splicing causing a premature stop codon and nonsense-mediated decay, expressed remnant levels of normally spliced DMD mRNA. Quantitative Western blot enabled correlation of wild-type dystrophin and clinical severity, with $0 \%-5 \%$ dystrophin conferring a Duchenne phenotype, $10 \% \pm 2 \%$ a Becker phenotype, and $15 \% \pm 2 \%$ dystrophin associated with myalgia without manifesting weakness.

\author{
Correspondence \\ Dr. Cooper \\ Sandra.cooper@sydney.edu.au
}

RELATED ARTICLE

\section{Editorial}

Molecular Diagnosis

in $100 \%$ of

Dystrophinopathies: Are

We There Yet?

Page e529

\begin{abstract}
*Deceased.
From the Kids Neuroscience Centre (L.B.W., S.J.B., A.B., F.J.E., H.J., S.A.S., G.L.O., E.C.O., N.F.C., K.J.J., S.T.C.), Kids Research Institute, The Children's Hospital at Westmead, New South Wales, Australia; Discipline of Child and Adolescent Health (L.B.W., S.J.B., A.B., F.J.E., S.A.S., G.L.O., E.C.O., N.F.C., K.J.J., S.T.C.), Faculty of Medicine and Health, The University of Sydney, Westmead, New South Wales, Australia; Analytic and Translational Genetics Unit (B.B.C., J.L.M., T.T., E.V., D.G.M., M.L.), Massachusetts General Hospital, Boston; Medical and Population Genetics (B.B.C., J.L.M. T.T., E.V., B.W., S.S., D.G.M., M.L.), and Center for Mendelian Genomics (B.B.C., J.L.M., E.V., B.W., S.S., D.G.M., M.L.), Broad Institute of MIT \& Harvard, Cambridge, MA; Functional Neuromics (F.J.E., S.T.C.), Children's Medical Research Institute, Westmead, New South Wales, Australia; Murdoch Children's Research Institute (S.S.), Parkville, Victoria, Australia; Department of Diagnostic Genomics (M.R.D., F.F., R.G.), PathWest Laboratory Medicine WA, Nedlands, Australia; Department of Clinical Genetics (S.A.S., A.M., K.J.J.), Children's Hospital at Westmead, New South Wales, Australia; Department of Genetic Medicine (M.C.T.), Westmead Hospital, New South Wales, Australia; Discipline of Genomic Medicine (M.C.T., A.M.), Sydney Medical School, The University of Sydney, New South Wales, Australia; Centre for Clinical Genetics (D.R.M.), Sydney Children's Hospital, Randwick, New South Wales, Australia; School of Women's and Children's Health (D.R.M., M.A.F.), UNSW Medicine, UNSW Sydney, Australia; Department of Neurology (M.A.F., H.S.), Sydney Children's Hospital, Randwick, New South Wales, Australia; Department of Clinical Genetics (A.M.), Nepean Hospital, Sydney, Australia; Genetic Health Service NZ (K.N.), Wellington, New Zealand; Neurology Laboratory (M.-X.W.), Royal Prince Alfred Hospital, Camperdown, New South Wales, Australia; Central Clinical School (M.-X.W.), Faculty of Medicine and Health, The University of Sydney, Camperdown, New South Wales, Australia; Anatomic Pathology (A.C., C.C., N.G., S.A.), The Children's Hospital at Westmead, New South Wales, Australia; Anatomic Pathologist (D.N.K.), Department of Pathology and Molecular Medicine, University of Otago, Wellington, New
\end{abstract} Zealand; and Harvard Medical School (D.G.M.), Boston, MA.

Go to Neurology.org/NG for full disclosures. Funding information is provided at the end of the article.

The Article Processing Charge was funded by the authors.

This is an open access article distributed under the terms of the Creative Commons Attribution-NonCommercial-NoDerivatives License 4.0 (CC BY-NC-ND), which permits downloading and sharing the work provided it is properly cited. The work cannot be changed in any way or used commercially without permission from the journal. 


\section{Glossary}

$\mathbf{b p}=$ base pair $\mathbf{C K}=$ creatine kinase $\mathbf{D M D}=$ Duchenne muscular dystrophy; gnomAD = Genome Aggregation Database; GTEx = Genotype-Tissue Expression; IGV = Integrative Genomic Browser; MLPA = multiplex ligation-dependent probe amplification; $\mathbf{m R N A}$ = messenger RNA; $\mathbf{n t}$ = nucleotide; RNA-seq = RNA sequencing; $\mathbf{R T}$-PCR = reverse transcription PCR; SNV = single nucleotide variant; $\mathbf{W B}=$ Western blot; WGA $=$ wheat germ agglutinin; $\mathbf{W T}=$ wild type .

\section{Conclusions}

Whole-genome sequencing relied heavily on RNA studies to identify DMD splice-altering variants. Short-read RNA sequencing was regularly confounded by the effectiveness of nonsense-mediated mRNA decay and low read depth of the giant $D M D$ mRNA. PCR of muscle cDNA provided a simple, yet informative approach. Highly relevant to genetic therapies for dystrophinopathies, our data align strongly with previous studies of mutant dystrophin in Becker muscular dystrophy, with the collective conclusion that a fractional increase in levels of normal dystrophin between $5 \%$ and $20 \%$ is clinically significant.

\section{Deciphering Dystrophinopathies: Can Whole-Genome Sequencing and RNA Studies Unlock Genetic Answers?

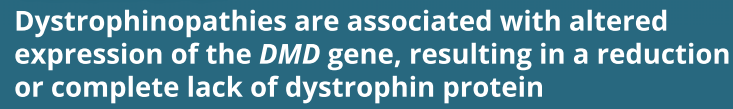 \\ or complete lack of dystrophin protein}

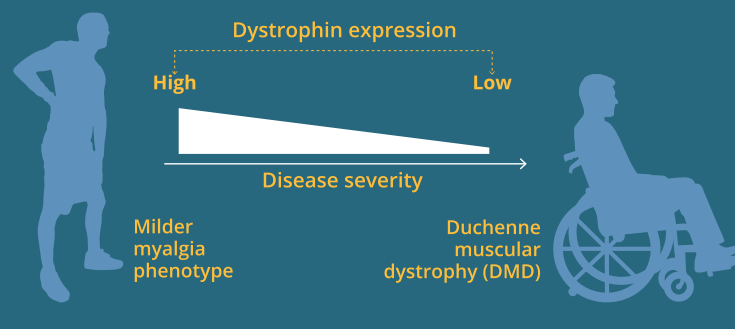

But, clinical diagnosis of dystrophinopathy does not always match the genetic diagnosis

\section{Study question}

Can whole-genome sequencing, transcriptomics, and dystrophin biochemistry confirm genetic diagnosis of dystrophinopathy?

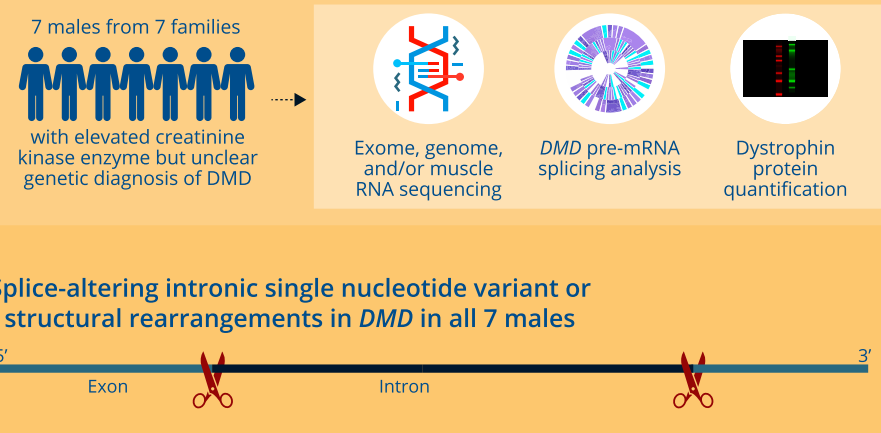

Dystrophin expression correlated with clinical severity in 4 males with causative variants

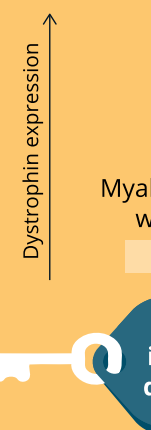

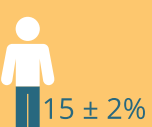

Myalgia without weakness Mild

Whole-genome sequencing and RNA sequencing can identify DMD splice-altering variants and confirm genetic diagnosis in individuals with suspected dystrophinopathy
doi:10.1212/NXG.0000000000000554

Copyright $\odot 2021$ American Academy of Neurology
Neurology Genetics
Duchenne muscular dystrophy (DMD) is a severe X-linked disorder primarily affecting approximately 1 in 5,000 male births. ${ }^{1-3}$ DMD shows a relentlessly progressive course, resulting in loss of ambulation in teens, and early mortality due to cardiac or respiratory involvement. ${ }^{4,5}$ Dystrophinopathies range clinically from the severe DMD to asymptomatic hyperCKemia. ${ }^{5-12}$ DMD is associated with the absence of dystrophin in muscle due to loss-of-function variants in the $D M D$ gene encoding dystrophin, ${ }^{5,6}$ whereas Becker muscular dystrophy (BMD) is associated with variants in $D M D$ that result in reduced levels of (mutated) dystrophin. ${ }^{5,6}$
The $D M D$ gene is the largest gene in the human genome, with numerous enormous introns. ${ }^{13,14}$ One-third of pathogenic $D M D$ variants are de novo, ${ }^{15,16}$ with most affected individuals bearing insertions or deletions (indels) of coding exons. ${ }^{15,17}$ Pathogenic DMD missense variants are rare, ${ }^{6,15,18}$ and noncoding variants are emerging as an important rare cause of dystrophinopathy. ${ }^{15,17,19,20}$ Approximately 5\% of patients clinically diagnosed with DMD do not have a genetic diagnosis after mutational analysis. ${ }^{5}$

Herein, we show the diagnostic application of whole-genome sequencing, transcriptomics, and dystrophin protein 
biochemistry to secure a genetic diagnosis for 13 affected males from 7 families with elevated creatine kinase (CK) who remained undiagnosed following multiplex ligationdependent probe amplification (MLPA) and exomic sequencing. Importantly, we identify 3 families with $D M D$ splicing variants who produce varying levels of mis-spliced transcripts that encode a premature stop codon and are targeted by nonsense-mediated decay, though express varying levels of remnant, normally spliced DMD mRNA. Therefore, quantitative Western blot (WB) of muscle biopsy specimens from these 3 dystrophin hypomorphs has uniquely enabled specific correlation of levels of wild-type (WT) dystrophin with clinical severity.

\section{Methods}

\section{Standard Protocol Approvals, Registrations, and Patient Consents}

This study was approved by the Children's Hospital at Westmead Human Research Ethics Committee (Biospecimen Bank_10/CHW/45) with informed, written consent from all participants.

We describe a retrospective cohort of boys diagnosed with $D M D$ variants from genomic and RNA studies, who had elevated $\mathrm{CK}$ and dystrophic muscle biopsies, and were undiagnosed after MLPA and exomic parallel sequencing.

\section{Immunohistochemistry and Western Blotting} Immunohistochemistry $^{21}$ and Western blotting ${ }^{22}$ were performed as previously described; WB used NuPAGE 3\%-8\% Tris-Acetate precast gels (Invitrogen by Thermo Fisher Scientific, NSW, Australia). Antibodies: for immunohistochemistry, muscle fiber membranes were stained with antidystrophin DYS1, DYS2, DYS3, and anti-spectrin SPEC1 (Leica Biosystems, VIC, Australia); with anti-mouse Alexa Fluor 555 secondary antibody, membranes were counterstained with wheat germ agglutinin-AF488 (WGA), and nuclei were stained with DAPI (Invitrogen Thermo Fisher Scientific). WBs were probed with DYS1 (Leica Biosystems), rabbit polyclonal dystrophin antibody (Rb-DMD; ab15277; Abcam), a-actinin-2 (4A3, gift from A. Beggs, Children's Hospital Boston, Boston, MA), sarcomeric actin (clone 5C5, A2172; Sigma-Aldrich), and the anti-mouse or anti-rabbit IgG light chain HRP-conjugated secondary antibodies (GE Healthcare, NSW, Australia). The rabbit polyclonal dystrophin antibody (Rb-DMD; ab15277; Abcam) detects a 10-fold serial dilution, whereas DYS2 is less sensitive (detects a 4-fold serial dilution). Therefore, ab15277 was selected due to provision of a more informative standard curve for semiquantification of dystrophin levels in the probands. Image ${ }^{23}$ was used to measure the densities of the patient and serially diluted controls bands to create a standard curve, as previously described. ${ }^{19}$ Semiquantitation of dystrophin levels was performed by comparing densities of the dystrophin band in patient sample relative to the standard curves of dystrophin in
2 age- and sex-matched controls across 3 experimental replicates.

\section{Massively Parallel Sequencing}

Whole-exome sequencing (probands and AI:1, AI:2, and AII: 2), PCR-free whole-genome sequencing (probands from families A and B, D-G), and RNA sequencing (RNA-seq; probands from families A, B, D, E, and G) were performed at the Broad Institute of Harvard and MIT as previously described. ${ }^{20}$ RNA-seq was performed for CII:2 at PathWest Laboratory Medicine WA as previously described for the fetal samples in reference 24 .

\section{Sanger Sequencing and RT-PCR}

RNA was extracted, and reverse transcription PCR (RT-PCR) was performed as previously described. ${ }^{25}$ Primers used for AII:1 have been previously described. ${ }^{20}$ The remaining primer details are as follows: Ex42F 5' -CAATGCTCCTGACCTC TGTG-3'; Ex43/44R 5'-CTGTCAAATCGCCCTTGTCG3'; LINC00251Ex3R 5' -CTGAAATGGGTGGGATGAAG-3'; LINC00251Ex2F 5'-GATGCCCCTTAACCAAGGAC-3'; Ex26F 5'-GATGCACGAATGGATGACAC-3'; Ex27R 5' ${ }^{\prime}$ TGTGCTACAGGTGGAGCTTG-3'; Ex26/27F 5'-GCAGTTGAAGAGATGAAGAGAGC-3'; Ex29R 5' -TGGGTTATCCTCTGAATGTCG-3'; In26PF 5' -AAACTTAGTTCGGCCCCATG-3'; Ex48F $5^{\prime}$-GTTAAATCATCTGCTGCTGTGG-3'; Ex54R 5' ${ }^{\prime}$-ACTGGCGGAGGTCTTTGG-3'; Ex49/52F 5'-ACTCAGCCAGTGAAGGCAAC-3'; Ex53R 5' -TCCTAAGACCTGCTCAGCTTC-3'; Ex51F 5'-CGACTGGCTTTCTCTGCTTG-3'; Ex50/52F 5' -CAAATCCTGCATTGTTGCAGG-3'; GAPDHEx3F 5'-TCACCAGGGCTGCTTTTAAC-3'; and GAPDHEx6R 5'-GGCAGAGATGATGACCCTTT-3'. Confirmation and segregation analysis of $D M D$ variants was performed by Sanger sequencing, ${ }^{21}$ except for family $F$ in which DNA was not available. Primers used for families A, D, E, and G have been previously described. ${ }^{20}$ The remaining primer details are as follows: family B-In43F 5'-TTTAGTTTCCAGCCACTCCTGTC-3' with chr8R 5'-TAGCAGGGGCAAGGGTTG-3' and chr8F 5' -TGCCTCTCCAGAATGAGGAC-3' with In43R 5'-CGGGGAACATCACACACC-3' to confirm insertion breakpoints; family C-In26F 5'-CGAAGGAAACTGGTATGTAG-3' with In26R 5'-AAAGCCGTATGACAGATTCG-3' to determine causative variant. PCR conditions were 5 minutes $95^{\circ} \mathrm{C} ; 35$ cycles- 30 seconds $95^{\circ} \mathrm{C}, 30$ seconds $58^{\circ} \mathrm{C}$, and 1 minute $72^{\circ} \mathrm{C}$; 8 minutes $72^{\circ} \mathrm{C}$; or as described in reference 20 .

\section{Whole-Genome Sequencing Analysis}

PCR-Free whole-genome sequencing was performed on an Illumina HiSeq X Ten using $2 \times 150$ paired end reads at $30 \times$ mean coverage. The sequencing reads were aligned to the GRCh37 genome reference and single nucleotide variants (SNVs), small insertions and deletions (indels) were detected using methods previously described in reference 20. A reanalysis of rare (Genome Aggregation Database $[$ gnomAD] $\mathrm{AF}<0.005) \mathrm{SNVs}$ and indels 
Table Clinical Presentation, DMD Variants, and Dystrophin Western Blot

\begin{tabular}{|c|c|c|c|c|c|c|c|}
\hline & All:1 & BIV:1 & CII:2 & DII:1 & ElI:1 & FII:6 & GII:1 \\
\hline $\begin{array}{l}\text { Clinical } \\
\text { symptoms }\end{array}$ & $\begin{array}{l}\text { Muscle pain, } \\
\text { fatigue, and } \\
\text { myoglobinuria } \\
\text { with exercise }\end{array}$ & $\begin{array}{l}\text { Proximal weakness } \\
\text { and bilateral calf } \\
\text { hypertrophy }\end{array}$ & $\begin{array}{l}\text { Progressive } \\
\text { limb-girdle } \\
\text { weakness and } \\
\text { falling regularly }\end{array}$ & $\begin{array}{l}\text { Proximal } \\
\text { weakness, } \\
\text { calf } \\
\text { hypertrophy, } \\
\text { and positive } \\
\text { Gowers sign }\end{array}$ & $\begin{array}{l}\text { Muscle } \\
\text { weakness } \\
\text { and calf } \\
\text { hypertrophy }\end{array}$ & $\begin{array}{l}\text { Proximal muscle } \\
\text { weakness, } \\
\text { positive Gowers } \\
\text { sign, and calf } \\
\text { hypertrophy }\end{array}$ & $\begin{array}{l}\text { Calf } \\
\text { hypertrophy } \\
\text { and positive } \\
\text { Gowers sign; } \\
\text { proximal } \\
\text { weakness, } \\
\text { elbow } \\
\text { contractures, } \\
\text { and learning } \\
\text { difficulties }\end{array}$ \\
\hline Onset & $15 y$ & $5 y$ & $9 y$ & $3.5 \mathrm{y}$ & $6 y$ & $3.5 \mathrm{y}$ & $5 y$ \\
\hline $\begin{array}{l}\text { Family } \\
\text { history }\end{array}$ & $\begin{array}{l}2 \text { affected } \\
\text { brothers } \\
\text { reporting myalgia } \\
\text { and serum CK } \\
\text { levels of } \\
300-14,700 \mathrm{U} / \mathrm{L}\end{array}$ & $\begin{array}{l}\text { Four-generation } \\
\text { family segregating } \\
\text { with an X-linked } \\
\text { muscular dystrophy } \\
\text { with } \\
\text { cardiomyopathy }\end{array}$ & Nil & Nil & $\begin{array}{l}\text { Has a } \\
\text { similarly } \\
\text { affected } \\
\text { brother }\end{array}$ & $\begin{array}{l}\text { The mother (Fl:6) } \\
\text { also has muscle } \\
\text { pain and elevated } \\
\text { serum CK levels of } \\
\sim 500 \mathrm{U} / \mathrm{L}\end{array}$ & Nil \\
\hline $\begin{array}{l}\text { Serum CK, } \\
\text { U/L }\end{array}$ & $1,400-7,500$ & 9,964 & 420 & 14,500 & 18,889 & 24,000 & $>12,000$ \\
\hline Ambulance & $\begin{array}{l}\text { Remains } \\
\text { ambulant }\end{array}$ & Remains ambulant & $\begin{array}{l}\text { Intermittent } \\
\text { use of a } \\
\text { wheelchair } \\
\text { from } 13 y\end{array}$ & $\begin{array}{l}\text { Wheelchair } \\
\text { dependent at } \\
13 \text { y }\end{array}$ & $\begin{array}{l}\text { Wheelchair } \\
\text { dependent } \\
\text { at } 9 \mathrm{y}\end{array}$ & $\begin{array}{l}\text { Remains } \\
\text { ambulant and toe } \\
\text { walking at } 9 \mathrm{y}\end{array}$ & $\begin{array}{l}\text { Wheelchair } \\
\text { dependent at } 7 \\
\text { y }\end{array}$ \\
\hline $\begin{array}{l}\text { Cardiac and } \\
\text { respiratory } \\
\text { involvement }\end{array}$ & Nil & $\begin{array}{l}\text { Normal } \\
\text { echocardiogram } \\
\text { cardiomyopathy in } \\
\text { BIII:2 and BIII:7 }\end{array}$ & $\begin{array}{l}\text { Nocturnal } \\
\text { bilateral } \\
\text { positive airway } \\
\text { pressure at } 28 \\
\text { y; normal } \\
\text { cardiac } \\
\text { function }\end{array}$ & $\begin{array}{l}\text { Cardiac- } \\
\text { reduced } \\
\text { contractility } \\
\text { (ejection } \\
\text { fraction } \\
30 \%-35 \% \text { ) } \\
\text { with normal } \\
\text { left ventricle } \\
\text { size }\end{array}$ & Nil & Nil & $\begin{array}{l}\text { Borderline } \\
\text { increase in } \\
\text { heart size at } 9 \text { y; } \\
\text { died at age } 10 \text { y } \\
\text { from cardiac } \\
\text { complications }\end{array}$ \\
\hline DMD variant & $\begin{array}{l}\text { Pseudoexon } \\
\text { inclusion in DMD } \\
\text { intron } 43 \mathrm{NM}_{-} \\
004006.2 \text { : } \\
\text { c. } 6290+30954 \mathrm{C}>\mathrm{T}\end{array}$ & $\begin{array}{l}\sim 116 \text { kb chr8 } \\
\text { insertion in DMD } \\
\text { intron } 43 \mathrm{NM}_{-} \\
004006.2 \text { : } \\
\text { c.6290+28627_- } \\
6290+28628 \text { ins } \\
\text { [TGTGGGCAAAGGC; } \\
\text { NR_038901.1: } \\
\text {-100749_430-3036; } \\
\text { NM_004006.2: } \\
6290+28628 \text { - } \\
6290+28751]\end{array}$ & $\begin{array}{l}\text { Pseudoexon } \\
\text { inclusion in } \\
D M D \text { intron } 26 \\
\text { NM_004006.2: } \\
\text { c.3603+820G>T }\end{array}$ & $\begin{array}{l}\text { Inversion of } \\
\text { DMD exon } 51 \\
\text { NM_ } \\
004006.2 \text { : } \\
\text { c.7310-2629_- } \\
\text { 7542+1338inv }\end{array}$ & $\begin{array}{l}\text { Inversion of } \\
D M D \text { exons } \\
1-18 \mathrm{NM}_{-} \\
004006.2: \text {. }^{-} \\
\text {1950935_- } \\
\text { 2293- } \\
\text { 1933inv }\end{array}$ & $\begin{array}{l}\text { Inversion of } D M D \\
\text { exons 1-44 NM_ } \\
\text { 004006.2:c.[NM_- } \\
\text { 001304548.1: } \\
\text { 6818-10658_NM_ } \\
\text { 004006.2: } \\
\text { 6438+112319inv; } \\
\text { 4233+10599_ } \\
\text { 5325+387dup; } \\
\text { 6117+6701_ } \\
6438+112319 \text { dup] }\end{array}$ & $\begin{array}{l}\text { Inversion of } \\
\text { DMD exons } \\
\text { 1-60 NM_- } \\
004006.2: c .[- \\
\text { 117965533_- } \\
\text { 9085-12259inv;- } \\
\text { 117965534_- } \\
\text { 117965551del; } \\
\text { 9085-12258_- } \\
\text { 9085-12196del] }\end{array}$ \\
\hline $\begin{array}{l}\text { Western } \\
\text { blot }\end{array}$ & $15 \% \pm 2 \%$ & $10 \% \pm 2 \%$ & $0 \%-5 \%$ & $0 \%-5 \%$ & $0 \%-5 \%$ & $0 \%-5 \%$ & $0 \%-5 \%$ \\
\hline
\end{tabular}

Abbreviations: $\mathrm{CK}=$ creatine kinase; $\mathrm{DMD}=$ Duchenne muscular dystrophy; $D M D=D M D$ gene or transcript.

revealed no pathogenic $D M D$ variants. The Manta tool from Illumina (PMID: 26647377) was used to identify structural variants or split read abnormalities within the $D M D$ gene. Putative structural variants were manually inspected within Integrative Genomic Browser (IGV) to validate and resolve exact breakpoints of structural rearrangements.

\section{RNA-seq Analysis}

RNA-seq analysis was performed as described in reference 20. Briefly, all samples were jointly processed and aligned with the Genotype-Tissue Expression Consortium (GTEx) ${ }^{26}$ to identify spliced reads only seen in patients or groups of patients and missing in controls. In addition, given the nature of the previously suspected diagnosis of a dystrophinopathy, in cases in which this approach did not lead to a diagnosis, exonic read depth was mapped in each patient and compared with controls and sashimi plots of patients were manually inspected using the IGV for the DMD gene. In cases, in which RNA-seq identified a mis-splicing event, patient exome and genomes were manually evaluated, depending on availability.

\section{Data Availability}

Data not published within this article are available by request from any qualified investigator. 


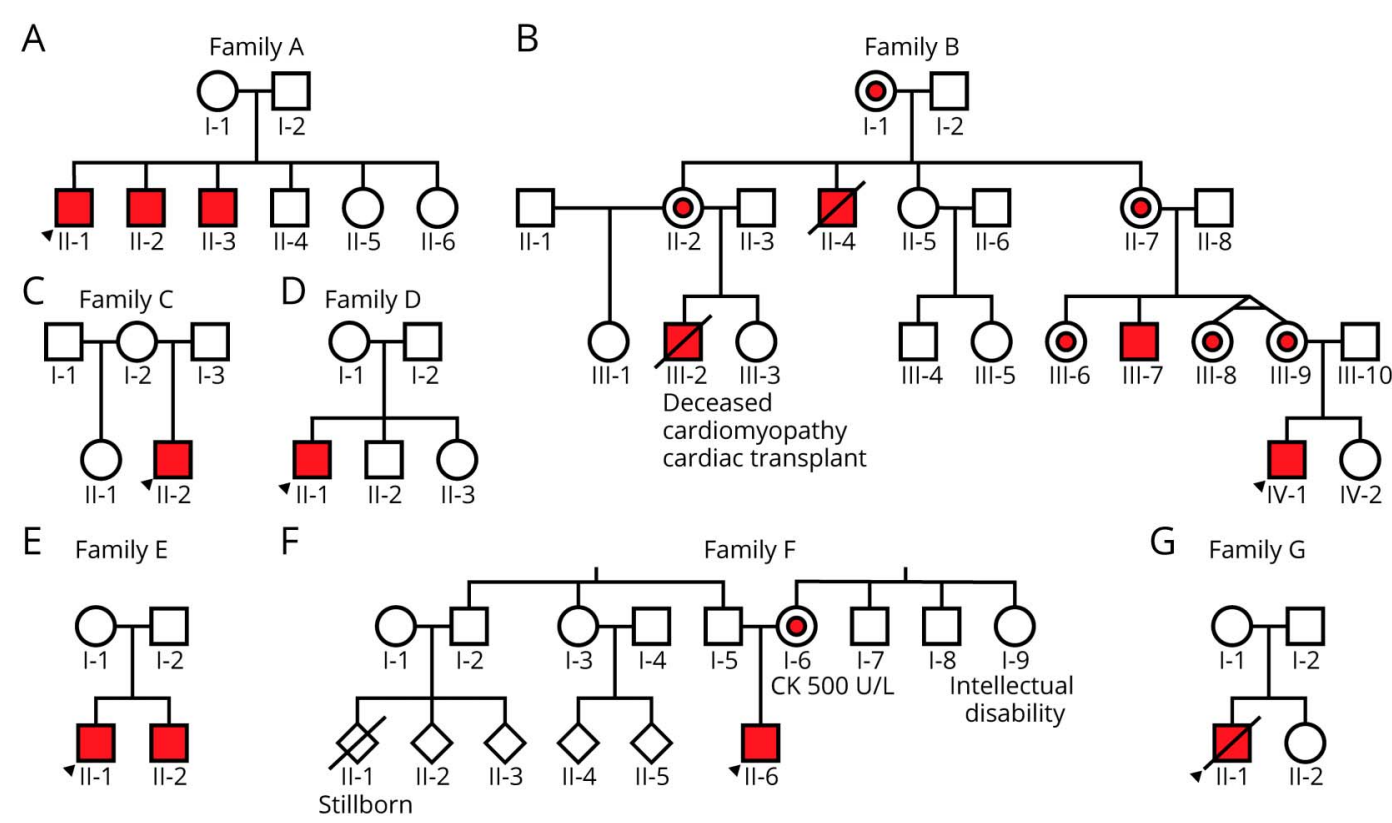

Index patient for each family denoted with black arrow. Affected members colored in red, and carriers part colored in red.

\section{Results}

\section{Clinical Presentation}

Four families have been described previously in reference 20: AII: 1 as N33; DII: 1 as C3; EII:1 as C4; and GII:1 as C2. Clinical presentation, $D M D$ variants, and dystrophin WB results are summarized in the table. Briefly, AII:1 presented at 15 years with muscle pain, fatigue, and episodes of myoglobinuria with exercise and elevated serum CK (CK 1,400-7,500 U/L, normal range $<200 \mathrm{U} / \mathrm{L}$ ). He has 2 affected brothers with myalgia and elevated serum CK (300-14,700 U/L (figure 1A). Family B is a 4-generation family with an X-linked muscular dystrophy with cardiomyopathy. BIII:2 was diagnosed with dilated cardiomyopathy in his 20s, underwent cardiac transplantation at age 29 years, and died of transplant-related complications at age 31 years. BIII:7 was diagnosed with BMD in his mid-teens. He has no known history of cardiomyopathy and remains ambulant in his 40s (figure 1B). BIV:1 showed elevated serum CK 9,964 U/ $\mathrm{L}$ at age 6 months. Now age 5 years, he has proximal muscle weakness, bilateral calf hypertrophy, and normal echocardiogram. CII:2 presented at age 9 years with progressive limb-girdle weakness, requiring intermittent use of a wheelchair from age 13 years and nocturnal bilateral positive airway pressure (BiPAP) from age 28 years. He has normal cardiac function with serum CK of $420 \mathrm{U} / \mathrm{L}$ at age 31 years (figure 1C). DII:1 presented at age 3.5 years with proximal weakness, calf hypertrophy, positive Gowers sign, and serum CK of 14,500 U/L. He required use of a wheelchair from age 13 years. Echocardiogram at age 17 years showed reduced contractility (ejection fraction 30\%-35\%) with normal left ventricle size (figure 1D). EII: 1 presented at age 6 years with muscle weakness, enlarged calves, and serum CK of $18,889 \mathrm{U} / \mathrm{L}$. He required use of a wheelchair at age 9 years and has no known cardiac or respiratory involvement. EII:1 has a similarly affected brother (figure 1E). FII:6 presented at age 3.5 years with proximal muscle weakness, positive Gowers sign, prominent calves, and serum $\mathrm{CK}$ of 24,000 U/L. He remains ambulant, but is toe walking at age 9 years. He has no known cardiac or respiratory involvement. FII:6's mother (FI:6) reports muscle pain and has elevated serum CK of $\sim 500 \mathrm{U} / \mathrm{L}$ (figure 1F). GII:1 presented at age 5 years with waddling gait, calf hypertrophy, positive Gowers sign, and serum CK levels of $>12,000 \mathrm{U} / \mathrm{L}$. He required use of a wheelchair from age 7 years. Echocardiogram at age 9 years showed borderline increase in heart size, and he died at age 10 years from cardiac complications (figure $1 \mathrm{G}$ ).

\section{DMD Diagnostic Genetic Testing}

$D M D$ MLPA and Sanger sequencing were performed and reported normal for AII:1, BIV:1, CII:2, DII:1, EII:1, and GII: 1. DMD MLPA performed for FII:6 revealed duplications of exons $31-37$ and 43-44, which were predicted to be in-frame and therefore considered inconsistent with his severe Duchenne-like phenotype, though with high clinical suspicion of causality. A genetic basis could not be identified via wholeexome sequencing (AII:1, BIV:1, DII:1, EII:1, FII:6, and GII: 1 , with duplications of exons 31-37 and 43-44 confirmed for FII:6) or massively parallel sequencing of a targeted neuromuscular gene panel (CII:2).

\section{Immunohistochemistry Demonstrates Dystrophin Abnormalities in Skeletal Muscle Biopsies}

Skeletal muscle immunohistochemistry for AII:1, BIV:1, DII: 1, EII:1, FII:6, and GII:1 confirms abnormalities in dystrophin 
A
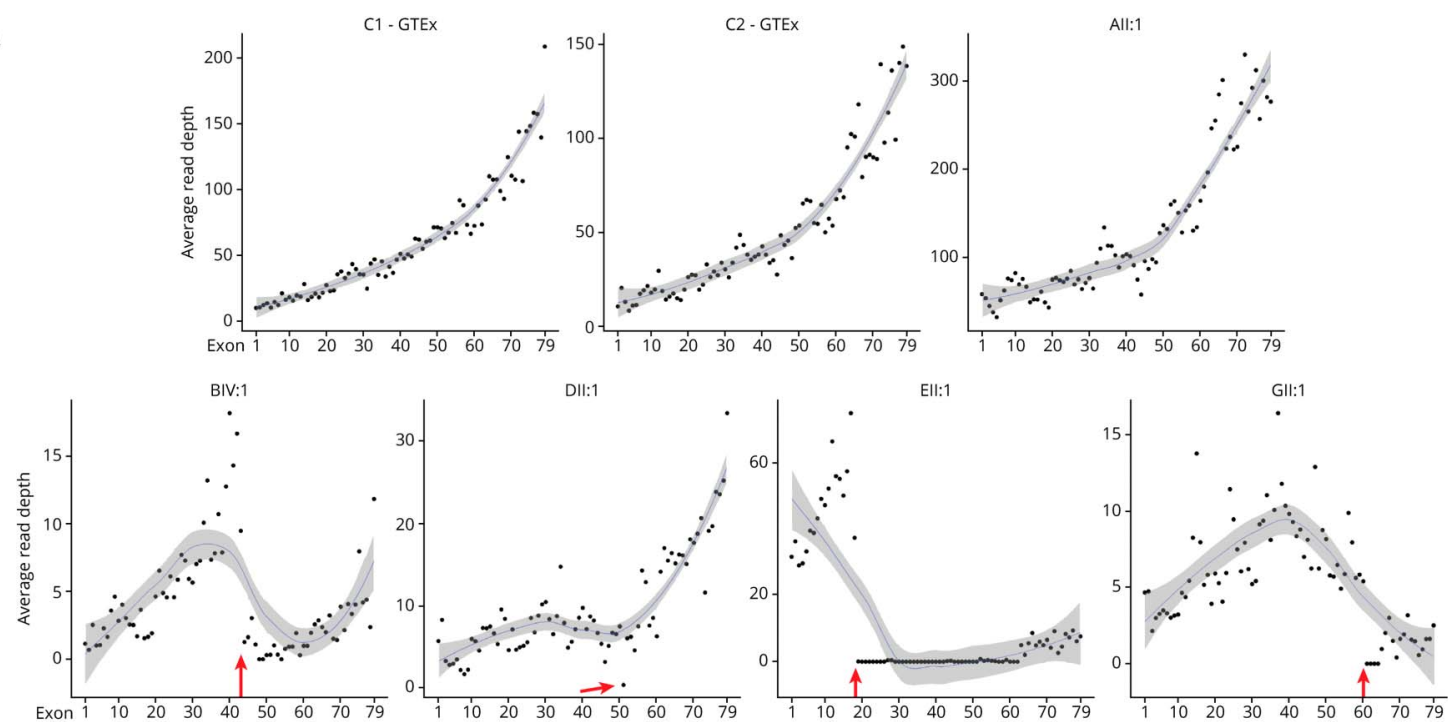

B

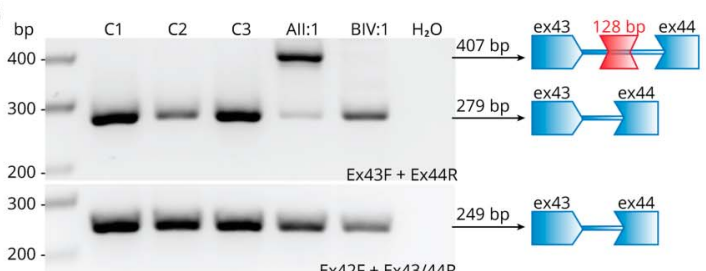

E

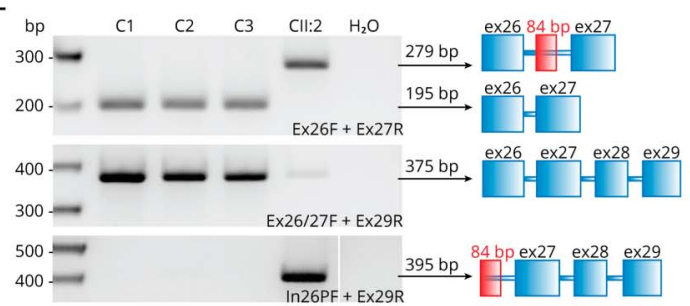

C

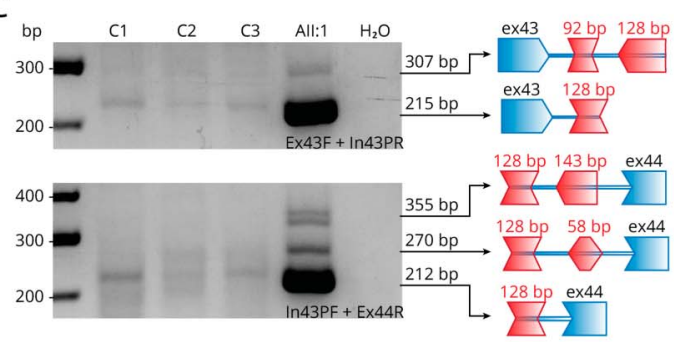

D
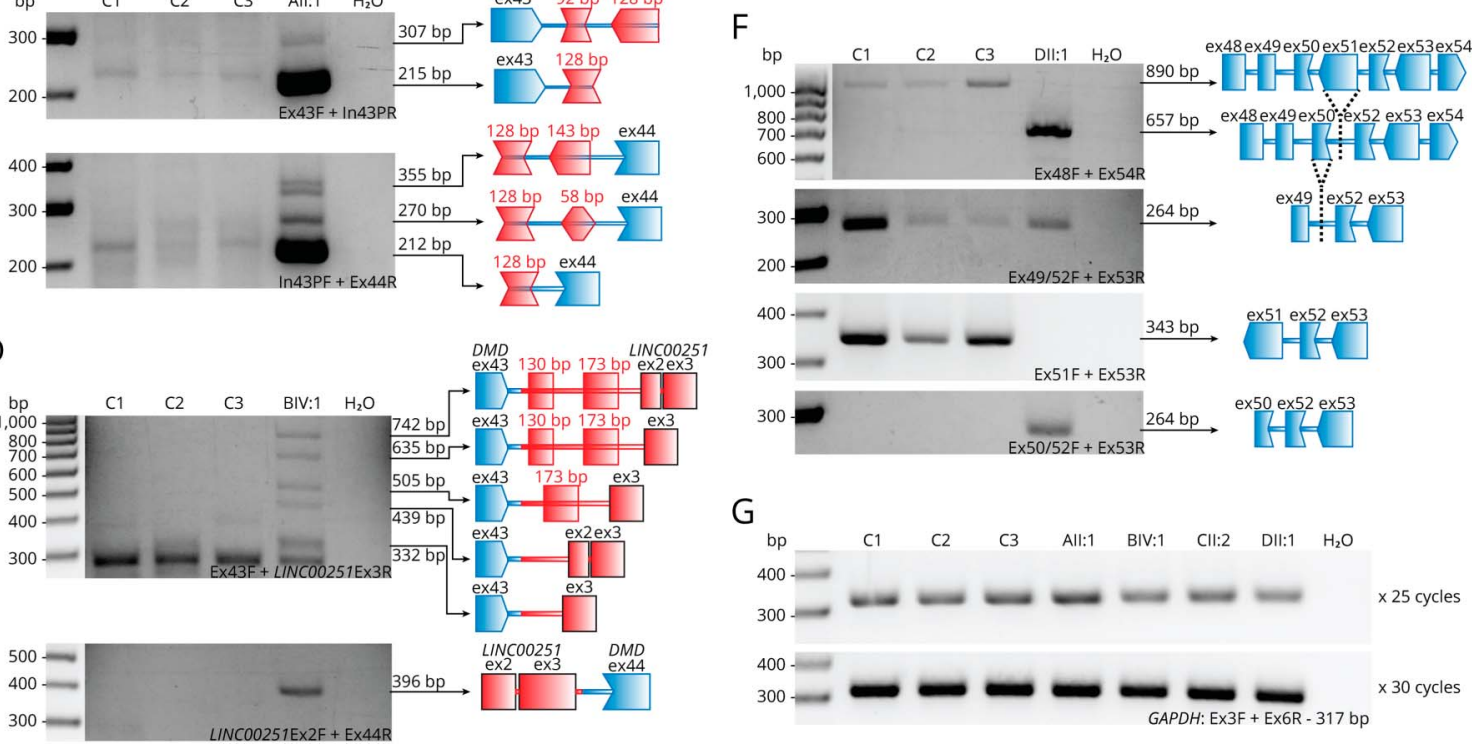

(A) RNA-seq read coverage of DMD exons in muscle RNA from All:1, BIV:1, DII:1, Ell:1, and GII:1 and 2 GTEx controls. Red arrows indicate the reduction in read depth, which corresponds with the location of DMD structural variants for BIV:1, DII:1, Ell:1, and GII:1. (B-G) RT-PCR studies of muscle-derived RNA of patients with splicing abnormalities and 3 male controls (C1, quadriceps, 6.5 years; C2, vastus lateralis, 17 years; C3, unknown, 20 years). Primers used are listed at the bottom right of each gel image and are labeled according to their location (exon; Ex, intron; In, pseudoexon; P) and orientation (forward; F, reverse; R). Bridging primers span a splice junction and are denoted by $X / Y$, where $X$ and $Y$ are exons the primer spans. All results were confirmed by Sanger sequencing. (B) RT-PCR showing reduced levels of correctly spliced DMD transcript (exons 43 and 44) in All:1 and BIV:1 compared with controls. All:1 shows the inclusion of a 128-bp pseudoexon. (C) Primers specific to the 128 bp pseudoexon revealed that the inclusion is specific to All:1 (Sanger sequencing showed that the faint bands in C1 were non-DMD sequences). Sequencing reveals that faint bands in All:1 correspond to multiple pseudoexons in DMD incorporated into a minority of DMD transcripts. (D) Various chr8 pseudoexons and LINC00251 exons are included in DMD transcripts as a result of the chr8 insertion in BIV:1. The lowest band detected in all samples in the top gel corresponds to non-DMD sequences. (E) RT-PCR confirms the inclusion of a 84-bp pseudoexon in CIl:2 in the majority of $D M D$ transcripts. Normal splicing can only be detected in very low levels in Cll:2 by bridging primers. The 92 bp pseudoexon is absent in control samples. (F) RT-PCR of DIl:1 confirms that exon 51 is absent from all DMD transcripts. A bridging primer indicates that skipping of both exons 50 and 51 is a low frequency event observed in both controls and DII:1. (G) GAPDH loading controls to indicate that similar concentrations of complementary DNA were used for both control and patient samples. $\mathrm{DMD}=$ Duchenne muscular dystrophy; $D M D=D M D$ gene or transcript; RT-PCR = reverse transcription PCR. 
Figure 3 Schematics of Variants Identified in Families A-G
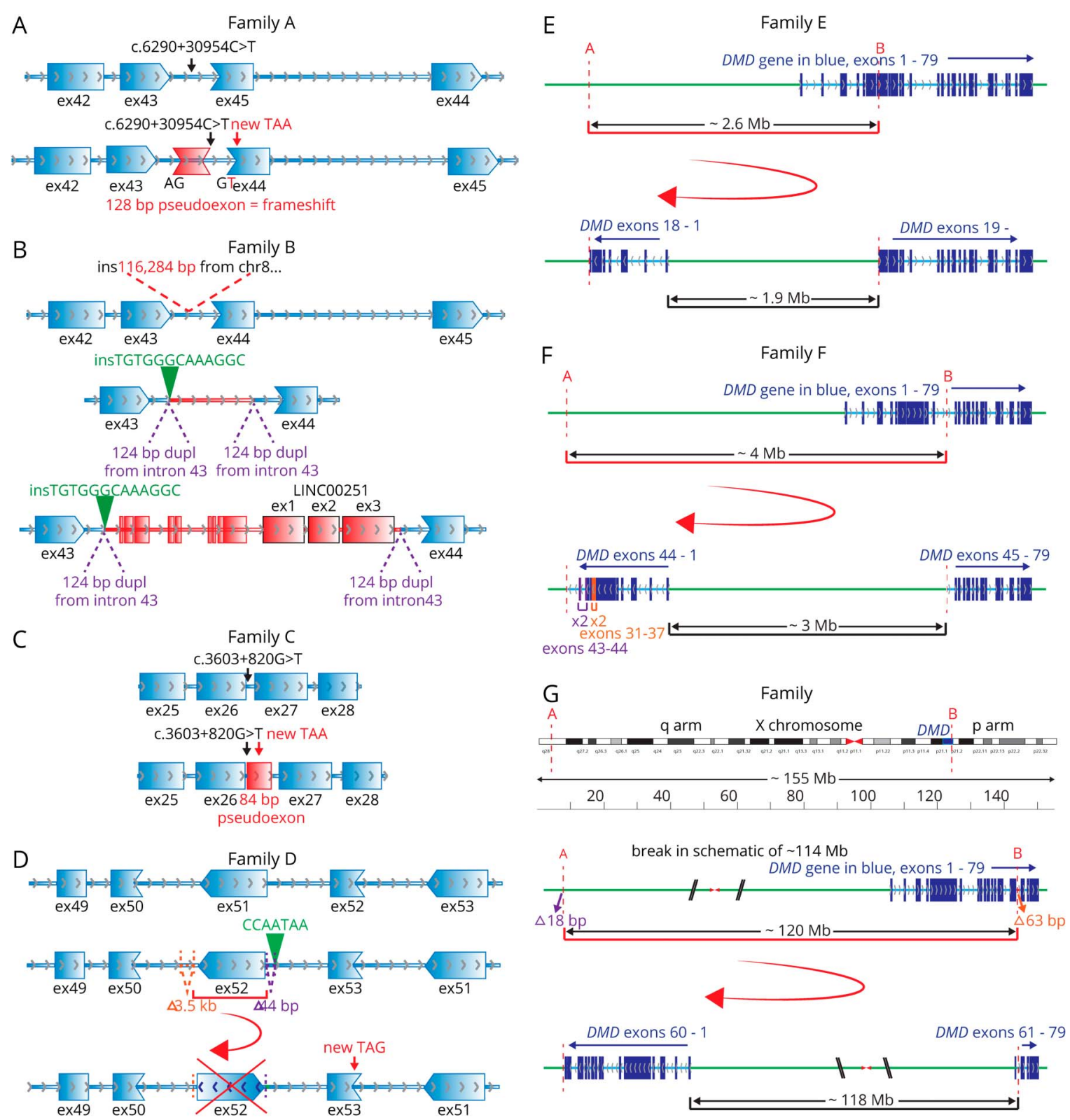

(A) Family A: intronic c.6290+30954C>T (black arrow) creates a cryptic donor splice site, leading to inclusion of a 128-bp pseudoexon (red, within DMD intron 43 ) into the $D M D$ mRNA, causing a frameshift and stop codon (red arrow) encoded by exon 44 (ex44). Gene direction is demonstrated by gray arrows. Reading frame between exons is shown by shape complementarity. (B) Family B: insertion of 116,284 bp of chr8 (red sequence) into DMD intron 43 . The insertion includes LINC00251 exons 1-3 (black outlined exons). A 124-bp sequence of intron 43 of DMD (chrX:32,276,895-32,277,018) is duplicated as part of the structural rearrangement and now flanks the chr8 insertion. In addition, there is an insertion of 13 bp (insGCCTTTGCCCACA, shown in green) adjacent to 1 copy of the 124-bp duplication. mRNA studies show evidence for numerous, different abnormal splicing events from $D M D$ exon 43 to various pseudoexons (red exons) and LINC00251 exons (red exons with black outlines) within the chr8 insertion. Low levels of normal DMD splicing (from exons 43 and 44; blue exons) are also observed. Frame of splicing in pseudoexons and LINC00251 exons not shown. (C) Family C: intronic c.3603+820G>T (black arrow) increases the strength of the polypyrimidine tract leading to use of a cryptic acceptor splice site (3/5 algorithms within Alamut Visual biosoftware predictions; MaxEntScan, NNSPLICE, and GeneSplicer) leading to inclusion of a 84-bp pseudoexon (red, within DMD intron 26) into the DMD mRNA, encoding a stop codon (red arrow) 39 nucleotides into the pseudoexon. Gene direction is demonstrated by gray arrows. Reading frame between exons is shown by shape complementarity. (D) Family D: inversion of DMD exon 51 and flanking adjacent intronic sequence. Flanking the structural rearrangement are 2 intronic deletions (orange 3.5 kb and purple $44 \mathrm{bp}$ ) and an insertion of CCAATA (green). mRNA studies show exon 51 skipping, causing a frameshift and a premature stop codon (TAG, encoded by exon 52; red arrow). (E) Family E: A 2.6-Mb inversion on the X chromosome between 2 breakpoints; A in intron 45 of CFAP47, 1.9 Mb upstream of exon 1 of DMD (GRCh37:chrX:35,180,364) and B in intron 18 of DMD (GRCh37:chrX:32,521,892, NM_004006.2). This reverses the orientation of exons 1-18 of DMD, which are now joined to CFAP47 sequences upstream of exon. The DMD gene is in blue, exons dark blue, and introns light blue. Intergenic sequence (non-DMD ChrX in green). (F) Family F: A 4.1-Mb inversion on the X chromosome between 2 breakpoints; A is 3.8 Mb upstream of exon 1 of DMD (GRCh37:chrX:36236087) and B in intron 44 of DMD (GRCh37:chrX:32122714). This reverses the orientation of exons 1-44 of DMD, which are now joined to intergenic sequence upstream of exon 1. This is accompanied by duplication of exons 31-37 (orange) and exons 43 and 44 (purple) around the breakpoint. (G) Family G: A 119.8-Mb inversion on the X chromosome between 2 breakpoints; A in an intergenic region on the $q$ arm of the X chromosome, $118 \mathrm{Mb}$ upstream of exon 1 of $D M D$ (GRCh37:chrX: $151,194,962)$, and B in intron 60 of DMD (GRCh37:chrX:31,379,010, NM_004006.2). This reverses the orientation of exons 1-60 of DMD, which are now joined to intergenic sequence upstream of exon 1. In addition, 2 deletions were identified at these breakpoints; an intronic 63 bp deletion (orange, GRCh37:chrX: 31,378,947-31,379,009) and an intergenic 18 bp deletion (purple, GRCh37:chrX:151,194,963-151,194,980). X chromosome displayed in unusual orientation with $\mathrm{q}$ arm to the left, so the $D M D$ gene is presented with exons in order. $D M D=D M D$ gene or transcript. mRNA $=$ messenger RNA. 
(figure e-1, links.lww.com/NXG/A367). Using 3 antidystrophin antibodies, AII:1 and BIV:1 showed reduced dystrophin staining, whereas DII:1, EII:1, FII:6, and GII:1 showed absent staining (figure e-1 absent dystrophin staining shown only for GII:1). WGA outlines the myofibers and labels the endomysium in patient and control skeletal muscle samples.

\section{Correlation of Splicing Analyses With Whole-Genome Sequencing Identifies Pathogenic Intronic and Structural Variants Inducing Abnormal DMD Splicing}

Six individuals (AII:1, BIV:1, DII:1, EII:1, FII:6, and GII:1) were subject to whole-genome sequencing, 6 individuals were subject to RNA-seq (AII:1, BIV:1, CII:2, DII:1, EII:1, and GII:1), and 4 individuals (AII:1, BIV:1, CII:2, and DII:1) were analyzed by RT-PCR of muscle-derived mRNA. Scrutiny of DMD transcripts (NM_004006.2, 11,058 nucleotides [nt] in length) shows typical $3^{\prime}$ bias in read depth (vastly more reads at the $3^{\prime}$ end compared with the $5^{\prime}$ end of DMD transcripts). Acknowledging $3^{\prime}$ bias, an abnormal profile of $D M D$ transcript read depth was apparent for BIV:1, DII:1, EII:1, and GII:1 (figure 2A), relative to multiple muscle controls from the GTEx consortium. ${ }^{26}$

Standard variant filtering approaches of genomic sequencing failed to identify most causal variants. RNA-seq identified abnormal pseudoexon inclusion into $D M D$ transcripts for families $\mathrm{A}$ and $\mathrm{C}$. The remaining pathogenic variants were identified only through the combination of whole-genome sequencing, bioinformatics, and RNA analyses.

A genetic diagnosis in AII: 1 was identified in a previous study $^{20}$ with a deep intronic pathogenic variant GRCh37: ChrX:32274692G >A; c.6290+30954C > T inducing partial mis-splicing of DMD. The DMD c.6290+30954C $>\mathrm{T}$ variant creates a cryptic donor 5 ' splice site resulting in inclusion of a variant-activated pseudoexon of $128 \mathrm{nt}$ inserted between exon 43 and exon 44, which encodes 59 missense amino acids and effects a frameshift, resulting in a premature termination codon encoded by exon 44 (figure 3A). RT-PCR confirmed abnormal inclusion of the variant-activated pseudoexon and residual normal splicing of DMD exons 42-43-44-45 (figure 2, $B$ and $\mathrm{C})$.

RNA-seq for BIV:1 showed low levels of DMD transcripts, with a distinct drop in reads from exon 44 onward (figure 2A, arrow). Bespoke realignment and analyses of WGS data identified insertion of $\sim 118,000 \mathrm{nt}$ of chromosome 8 (chr8) sequences within $D M D$ intron 43, encompassing the LINC00251 gene locus. RT-PCR showed that the chr8 insertion induced abnormal splicing of the $D M D$ gene (figure 3B). Multiple adverse events were detected that involved splicing from exon 43 of $D M D$ to various pseudoexons and

Figure 4 Western Blot Panel for All Patients

A.a \begin{tabular}{llll} 
DMD control \\
\hline $1 / 2$ & $3 / 4$ & $5 / 6$ & $9 / 10$
\end{tabular}
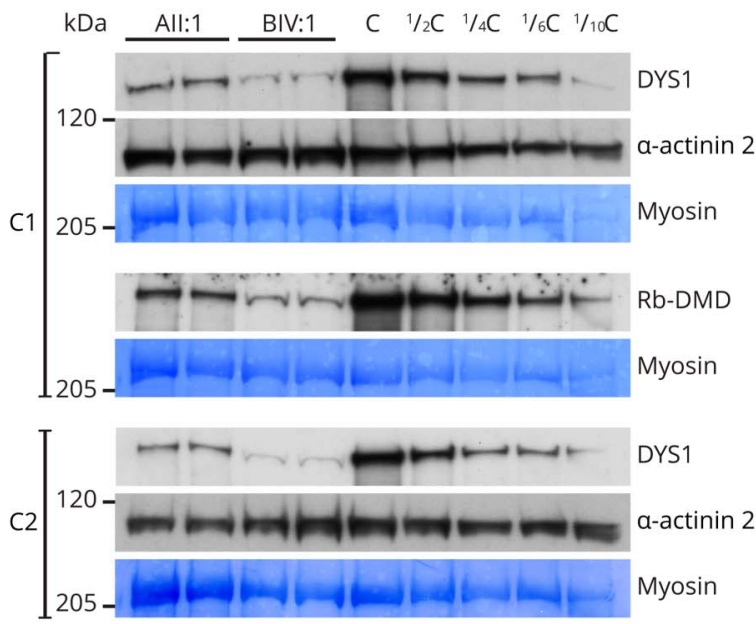

A.b

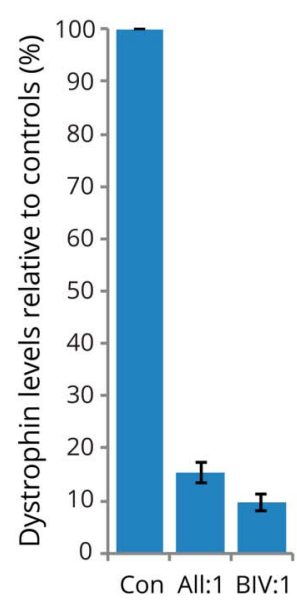

B

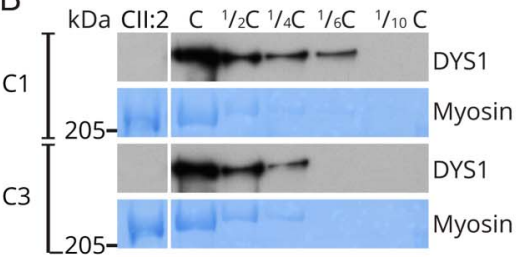

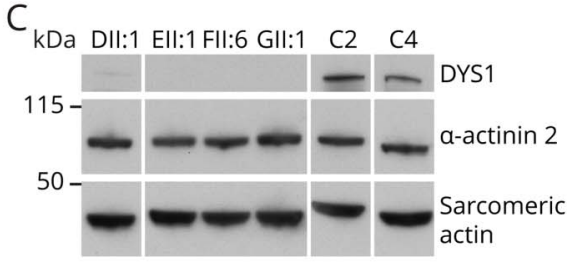

(A.a) Western blot was performed on skeletal muscle from index patients from families $A$ and $B$ (All:1 and BIV:1) against DYS1 (rod domain epitope) and Rb-DMD (C-terminal epitope) with serial dilutions (1/2,3/4,5/6, and 9/10) human control skeletal muscle. Muscle lysate derived from an individual with Duchenne muscular dystrophy and undetectable levels of dystrophin by Western blot (DMD control; deltoid, 14-year-old boy, GRCh37:chrX:32364116G>A, NM_004006.2: c.5530C>T, p.Arg1844*) were added to diluted controls to normalize total protein loading in each lane of the gel. Loading controls: a-actinin-2 and myosin (coomassie). (A.b) Image $\rfloor^{23}$ was used to measure the densities of the patient and serially diluted controls bands to create a standard curve. Quantification of relative dystrophin levels was performed by comparing patient sample densities to the control standard curves across the 3 gels shown. All:1 demonstrates 15.5\% $\pm 1.9 \%$ levels of dystrophin protein relative to controls. BIV:1 demonstrates $9.6 \% \pm 1.7 \%$ levels of dystrophin protein relative to control. (B) Western blot analysis on skeletal muscle from patient CIl:2 against DYS1 shows undetectable levels of dystrophin compared with controls. Loading controls: myosin (coomassie). (C) Western blot analysis on skeletal muscle from patients DII:1, Ell: 1, FII:6, and GII:1 against DYS1 compared with human control skeletal muscle. DIl:1 shows very low levels of dystrophin. Ell:1 Fll:6, and Gll:1 show undetectable levels of dystrophin. Loading controls: a-actinin-2 and sarcomeric actin. Male controls used: C1, tibialis anterior, 16 years; C2 unknown, 5.5 years; C3, unknown, 14 years; C4, quadriceps, 4.5 years. DMD = Duchenne muscular dystrophy. 
LINC00251 exons within the chr8 insertion. Sanger sequencing with bespoke PCR over the breakpoints on gDNA confirmed the chr8 inclusion in intron 43 and provided a diagnostic assay that confirmed segregation of the insertion within the family pedigree. Normal splicing of $D M D$ exons 42-43-44-45 was observed as a low-frequency event (figure 2, B and D).

For CII:2, manual analysis of RNA-seq data identified abnormal inclusion of $84 \mathrm{nt}$ from intron 26 into a majority of $D M D$ transcripts (figure 3C). Sanger sequencing of the genomic region in gDNA from CII:2 identified a deep intronic variant GRCh37: ChrX:32471959C $>\mathrm{A}, \mathrm{c} .3603+820 \mathrm{G}>\mathrm{T}$ that was absent in gno$\mathrm{mAD}$. The $D M D$ c.3603+820G $>\mathrm{T}$ variant in intron 26 disrupts an $A G$, creating an AG-exclusion zone between an available consensus lariat branch point and $3^{\prime}$ splice site. ${ }^{27}$ Spliceosomal use of a naturally occurring consensus $5^{\prime}$ splice site sequence and this strengthened $3^{\prime}$ splice site result in the inclusion of a variantactivated pseudoexon into a majority of $D M D$ transcripts, encoding 19 missense amino acids followed by a stop codon (figure 3C). RT-PCR confirmed abnormal inclusion of the variant-activated pseudoexon into $D M D$ transcripts and residual, low levels of $D M D$ transcripts with normal splicing of exons 2526-27 (figure 2E). Sanger sequencing confirmed that the c. $3603+820 \mathrm{G}>\mathrm{T}$ variant was de novo in CII:2.

For DII:1, RNA-seq in a previous study ${ }^{20}$ showed low levels of $D M D$ transcripts with exon 51 skipping, inducing a frameshift and premature stop codon encoded by exon 52 (r.7310 7542del, p.Ser2437Cysfs*33, figure 3D). Interrogation of WGS determined presence of a $D M D$ structural rearrangement rendering $D M D$ exon 51 in the reverse orientation and unable to be spliced into the DMD mRNA, confirmed by Sanger sequencing. RT-PCR confirms exon 51 skipping as the predominant mis-splicing event in DII:1, with skipping of exons 50 and 51 a low-frequency, in-frame event observed in both DII: 1 and controls (figure 2F). Low levels of exon 50 and 51 skipping are consistent with low levels of dystrophin detected by WB analysis (figure 4C).

RNA-seq showed an abrupt loss of transcripts after exon 18 in EII:1, as previously described in reference 20 (figure 2). WGS showed evidence for an inversion within the $D M D$ gene reversing the orientation of exons 1-18 of $D M D$, which are now joined to intergenic sequences upstream of exon 1, explaining the presence of abruptly terminating exon 1-18 transcripts transcribed from the $D M D$ promoter (figure $3 \mathrm{E}$ ). The $1.9 \mathrm{Mb}$ intergenic region included in the inversion contains FAM47A, FAM 47B, and TMEM47 genes. Sanger sequencing of genomic DNA over the breakpoints confirmed the inversion.

FII:6 with in-frame duplications of exons $31-37$ and 43-44 identified on DMD MLPA, was shown by WGS to have a larger, more complex structural rearrangement (figure $3 \mathrm{~F}$ ), which reverses the orientation of exons 1-44 of DMD which are now joined to intron 45 of CFAP47, upstream of exon 1 . Expression of CFAP47 is likely to be disrupted. However, the clinical significance of loss of CFAP47 expression is unknown.
In GII:1, RNA-seq in a previous study ${ }^{20}$ showed low read count for $D M D$ transcripts, with evidence for even fewer reads from exon 60. Closer scrutiny of whole-genome sequencing data identified a structural rearrangement reversing the orientation of exons 1-60 of $D M D$, which are now joined to intergenic sequences upstream of exon 1 (figure 3G). Sanger sequencing of genomic DNA over the breakpoints confirmed the inversion.

\section{WB Analyses Define the Threshold of WT Dystrophin Conferring Clinical Phenotypes of Duchenne to Myalgia}

Our splicing studies reveal that AII:1, BIV:1, and CII:2 each have residual levels of normally spliced $D M D$ transcripts, with abnormal splicing events apparently targeted for degradation by nonsense-mediated decay (figure 2, B-E). Therefore, these individuals uniquely provide an opportunity to quantify levels of WT dystrophin and correlate with clinical phenotype. Quantitative WB (figure 4) using skeletal muscle biospecimens reveals (1) $\sim 15 \% \pm 2 \%$ normal dystrophin levels in AII:1, correlating with a myalgia phenotype without apparent weakness; (2) $\sim 10 \% \pm 2 \%$ levels of dystrophin in BIV:1 (figure 4A) with Becker muscular dystrophy, mild weakness, and cardiac phenotype; and (3); $0 \%-5 \%$ levels of dystrophin in affected individuals who present with a severe Becker (CII:2) or Duchenne phenotype (DII:1, EII:1, FII:6, and GII:1) (figure 4, B and C).

\section{Discussion}

Our study further substantiates $D M D$ splicing variants as an important causal basis for males presenting with symptoms consistent with a dystrophinopathy, for whom exomic sequencing approaches or MLPA return negative findings. A causal splicing variant in $D M D$ was identified in all 7 families within our dystrophinopathy cohort and includes 13 affected males presenting with hyperCKemia with pain and/or muscle weakness and/or cardiac involvement.

Importantly, identification of the causative variant in $D M D$ within this hard-to-diagnose cohort required deployment of WGS, RNA-seq and/or bespoke RT-PCR studies of mRNA isolated from skeletal muscle. For example, for CII:2, RNAseq was crucial to identify the inclusion of an 84 base pair (bp) pseudoexon encoding a frameshift which prompted Sanger sequencing of this region, which lead to the identification of the casual intron 26 c.3603+820G $>\mathrm{T}$ variant, which was undetectable by gene panel testing, Sanger sequencing of the individual exons or MLPA. Although multiple genetic investigations are costly and not available currently to many diagnostic laboratories, costs incurred through muscle biopsy, WGS, or RNA studies are insignificant relative to the cost burden to health services for dystrophinopathy cases, for example, the heart transplantation for family $B$. A precise genetic diagnosis for an $\mathrm{X}$-linked disorder has important and widereaching implications for genetic, prenatal, and prognostic counseling across the wider family unit and can inform 
reproductive decision making. In addition, a genetic diagnosis could enable future customizable treatments such as splicemodulating antisense oligonucleotide drugs, ${ }^{28}$ which would theoretically be applicable to families A, C, and D.

Although WGS and RNA-seq bring powerful adjunct tests to clinical genomics, shortcomings of short read massively parallel sequencing were clearly observed in this study. As human exons are typically $100-150 \mathrm{bp}$ in length, short-read RNA-seq is limited in that a single read does not effectively bridge multiple exons. Most significantly, RNA-seq for BIV:1, DII:1, EII:1, and GII:1 was confounded by the effectiveness of nonsense-mediated decay, an innate surveillance mechanism that degrades mRNA bearing a premature stop codon. ${ }^{15,17}$ We suspect that the reason we do not see a profound reduction in read depth for AII: 1 (figure $2 \mathrm{~A}$ ) is due in part to higher read depth across the transcriptome, including $D M D$, and in part to the residual normal splicing of a significant proportion of $D M D$ transcripts (27\%). Nonsense-mediated decay amplifies inherent challenges associated with RNA-seq of very large mRNAs, where mRNA capture and sequencing library construction result in a characteristic bias in read depth, with vastly more reads at the $3^{\prime}$ end than the $5^{\prime}$ end of a very long mRNA. Notably, common disease genes in neuromuscular disorders are among the largest coding mRNAs in humans, with DMD mRNA $\sim 14,000 \mathrm{nt}, N E B$ mRNA $\sim 50,000 \mathrm{nt}$, and TTN mRNA $\sim 100,000 \mathrm{nt}$. Therefore, ribosomal RNA depletion and/or long read RNA-seq approaches, which display reduced $3^{\prime}$ bias, may be more effective for diagnosing neuromuscular disorders.

Regular data filtering approaches of genomic sequencing failed to identify most of the causal variants (excluding families A and C found on RNA-seq). This is likely due to the nature of the variants themselves (noncanonical splice affecting variants or structural variants), small read lengths, and mapping restrictions against the reference sequence. The structural rearrangement within $D M D$ intron 43 of family B took extensive bioinformatic analysis to delineate, even when our RT-PCR (data not shown) and RNA-seq studies had indicated intron 43 as the likely location of the problem. Although (in retrospect) the copy number variation of the duplicated region of chr8 is evident, informatics approaches to map split reads to precisely define the breakpoints were challenging and ultimately required both informatics and Sanger sequencing of PCR amplicons to fully resolve. Of note, the bespoke PCR uniquely identifying the $D M D$ intron 43 structural rearrangement was clinically preferred as the diagnostic test for segregation and carrier testing due to its greater specificity relative to the microarray to detect the chr8 copy number variation. The availability of a validated bespoke PCR also means that carrier females in this family could have prenatal diagnosis of male pregnancies.

Although families B, D, and G have cardiac involvement that is common in dystrophinopathy, families A, C, E, and F do not have reported cardiac symptoms and are being monitored for possible development of cardiac symptoms. The profound cardiac involvement in family B raises suspicion of potential differences in $D M D$ pre-mRNA mis-splicing between cardiac and skeletal muscle activated by the insertion of $118 \mathrm{~kb}$ of $\mathrm{Chr} 8$ sequences containing the LINC00251 gene. It is plausible that the severe cardiac involvement in family B is due to more fully penetrant $D M D$ mis-splicing in cardiac tissue compared with skeletal muscle. Unfortunately, no stored cardiac specimens were available for mRNA studies from other affected family members who had undergone transplant surgery. It is also possible that levels of inclusion of the frameshifting pseudoexon in family $\mathrm{C}$ may differ between skeletal muscle (and potentially between different skeletal muscles) and cardiac muscle.

In conclusion, we highlight $D M D$ splicing variants as an important causal basis in individuals with a suspected dystrophinopathy who remain undiagnosed after exomic sequencing or MLPA approaches. Causative DMD variants identified in AII:1, BIV:1, and CII:2 that induce partial missplicing of DMD mRNA provided us with a unique opportunity; each affected individual produced varying levels of remnant, normally spliced DMD mRNA, with all mis-spliced transcripts encoding a premature stop codon and targeted by nonsense-mediated decay. Therefore, we were able to use quantitative WB to correlate levels of WT dystrophin with clinical severity. We establish a steep therapeutic range of WT dystrophin protein levels (figure 4A); with $\sim 15 \%$ WT dystrophin associated with myalgia without apparent weakness, $\sim 10 \%$ levels of WT dystrophin associated with Becker muscular dystrophy, mild weakness, and cardiac phenotype, and $<5 \%$ WT dystrophin associated with a severe Becker or Duchenne-like phenotype. Our findings broadly concur with previous studies correlating levels of mutated dystrophin in BMD with clinical severity, ${ }^{7,29-31}$ supporting the notion of a functional redundancy within the spectrin-like repeats of the dystrophin rod domain. Of great relevance to international efforts to develop genetic therapies in DMD, our data provide compelling evidence that with early intervention, only fractional increases in levels of dystrophin are likely to result in clinical improvement.

\section{Acknowledgment}

The authors thank the families for their invaluable contributions to this research and the clinicians and health care workers involved in their assessment and management. For cytogenomic analysis on family B, the authors thank the laboratory of Artur P. Darmanian, Sydney Genome Diagnostics, within the Children's Hospital at Westmead, NSW, Australia. For bespoke PCR segregation analysis on extended family members from family $\mathrm{B}$, the authors thank Dr. Bruce Bennetts, Dr. Gladys Ho, and Sydney Genome Diagnostics, Western Sydney Genetics Program, The Children's Hospital at Westmead, NSW, Australia. For histopathology on family C, the authors thank the Department of Anatomical Pathology, South Eastern Area Laboratory Services, Sydney Children's Hospital, Randwick, NSW, Australia. The Genotype-Tissue Expression (GTEx) Project was supported by the Common 
Fund of the Office of the Director of the NIH (commonfund.nih.gov/GTEx) and by the NCI, NHGRI, NHLBI, NIDA, NIMH, and NINDS. The datasets used for the analyses described in this manuscript were obtained from dbGaP at http://www.ncbi.nlm.nih.gov/gap through dbGaP accession number phs000424.v7.p2.

\section{Study Funding}

This study was supported by the National Health and Medical Research Council of Australia (APP1048816 and APP1136197 S.T.C., APP1080587 S.T.C., D.G.M.). S.J. Bryen is supported by a Muscular Dystrophy New South Wales $\mathrm{PhD}$ scholarship. E.C. Oates is supported by NHMRC ECR: GNT1090428. WES, WGS, and RNA-seq was provided by the Broad Institute of MIT and Harvard Center for Mendelian Genomics (Broad CMG) and was funded by the National Human Genome Research Institute, the National Eye Institute, and the National Heart, Lung and Blood Institute's NIH grant UM1 HG008900 to D.G.M. and Heidi Rehm.

\section{Disclosure}

S.T. Cooper is director of Frontier Genomics Pty Ltd. (Australia). Frontier Genomics has not traded (as of September 25, 2020). Frontier Genomics Pty Ltd. (Australia) has no existing financial relationships that will benefit from publication of these data. N.F. Clarke is deceased; disclosures are not included for this author. The remaining coauthors do not have any relationships, financial or otherwise, that may result in a perceived conflict of interest. Go to Neurology.org/NG for full disclosures.

\section{Publication History}

Received by Neurology: Genetics May 1, 2020. Accepted in final form November 19, 2020.

Appendix Authors

\begin{tabular}{|c|c|c|}
\hline Name & Location & Contribution \\
\hline $\begin{array}{l}\text { Leigh B. Waddell, } \\
\text { PhD }\end{array}$ & $\begin{array}{l}\text { The Children's } \\
\text { Hospital at } \\
\text { Westmead, New } \\
\text { South Wales, } \\
\text { Australia }\end{array}$ & $\begin{array}{l}\text { Concept and design of } \\
\text { the study, acquisition } \\
\text { and analysis of data, } \\
\text { and drafting the } \\
\text { manuscript/figures for } \\
\text { intellectual content }\end{array}$ \\
\hline $\begin{array}{l}\text { Samantha J. Bryen, } \\
\text { BSc (Hons) }\end{array}$ & $\begin{array}{l}\text { The Children's } \\
\text { Hospital at } \\
\text { Westmead, New } \\
\text { South Wales, } \\
\text { Australia }\end{array}$ & $\begin{array}{l}\text { Concept and design of } \\
\text { the study, acquisition } \\
\text { and analysis of data, } \\
\text { and drafting the } \\
\text { manuscript/figures for } \\
\text { intellectual content }\end{array}$ \\
\hline $\begin{array}{l}\text { Beryl B. Cummings, } \\
\text { PhD }\end{array}$ & $\begin{array}{l}\text { Broad Institute of MIT } \\
\text { \& Harvard, } \\
\text { Cambridge, MA }\end{array}$ & $\begin{array}{l}\text { Acquisition and analysis } \\
\text { of data and drafting the } \\
\text { manuscript/figures for } \\
\text { intellectual content }\end{array}$ \\
\hline $\begin{array}{l}\text { Adam Bournazos, } \\
\text { BSc (Hons) }\end{array}$ & $\begin{array}{l}\text { The Children's } \\
\text { Hospital at } \\
\text { Westmead, New } \\
\text { South Wales, } \\
\text { Australia }\end{array}$ & $\begin{array}{l}\text { Acquisition and analysis } \\
\text { of data and drafting the } \\
\text { manuscript/figures for } \\
\text { intellectual content }\end{array}$ \\
\hline
\end{tabular}

Appendix (continued)

\begin{tabular}{|c|c|c|}
\hline Name & Location & Contribution \\
\hline $\begin{array}{l}\text { Frances J. Evesson, } \\
\text { PhD }\end{array}$ & $\begin{array}{l}\text { The Children's } \\
\text { Hospital at } \\
\text { Westmead, New } \\
\text { South Wales, } \\
\text { Australia }\end{array}$ & $\begin{array}{l}\text { Acquisition and analysis } \\
\text { of data and drafting the } \\
\text { manuscript/figures for } \\
\text { intellectual content }\end{array}$ \\
\hline $\begin{array}{l}\text { Himanshu Joshi, B } \\
\text { Software } \\
\text { Engineering, B } \\
\text { Business (Finance) }\end{array}$ & $\begin{array}{l}\text { The Children's } \\
\text { Hospital at } \\
\text { Westmead, New } \\
\text { South Wales, } \\
\text { Australia }\end{array}$ & $\begin{array}{l}\text { Acquisition and analysis } \\
\text { of data and drafting the } \\
\text { manuscript/figures for } \\
\text { intellectual content }\end{array}$ \\
\hline $\begin{array}{l}\text { Jamie L. Marshall, } \\
\text { PhD }\end{array}$ & $\begin{array}{l}\text { Broad Institute of MIT } \\
\text { \& Harvard, } \\
\text { Cambridge, MA }\end{array}$ & $\begin{array}{l}\text { Acquisition and analysis } \\
\text { of data }\end{array}$ \\
\hline Taru Tukiainen, PhD & $\begin{array}{l}\text { Broad Institute of MIT } \\
\text { \& Harvard, } \\
\text { Cambridge, MA }\end{array}$ & $\begin{array}{l}\text { Acquisition and analysis } \\
\text { of data }\end{array}$ \\
\hline $\begin{array}{l}\text { Elise Valkanas, BA } \\
\text { (Biology) }\end{array}$ & $\begin{array}{l}\text { Broad Institute of MIT } \\
\text { \& Harvard, } \\
\text { Cambridge, MA }\end{array}$ & $\begin{array}{l}\text { Acquisition and analysis } \\
\text { of data }\end{array}$ \\
\hline $\begin{array}{l}\text { Ben Weisburd, BS } \\
\text { (Computer Sc) }\end{array}$ & $\begin{array}{l}\text { Broad Institute of MIT } \\
\text { \& Harvard, } \\
\text { Cambridge, MA }\end{array}$ & $\begin{array}{l}\text { Acquisition and analysis } \\
\text { of data }\end{array}$ \\
\hline Simon Sadedin, PhD & $\begin{array}{l}\text { Broad Institute of MIT } \\
\text { \& Harvard, } \\
\text { Cambridge, MA }\end{array}$ & $\begin{array}{l}\text { Acquisition and analysis } \\
\text { of data }\end{array}$ \\
\hline Mark R. Davis, PhD & $\begin{array}{l}\text { PathWest Laboratory } \\
\text { Medicine WA, } \\
\text { Nedlands, Australia }\end{array}$ & $\begin{array}{l}\text { Acquisition and analysis } \\
\text { of data }\end{array}$ \\
\hline Fathimath Faiz, PhD & $\begin{array}{l}\text { PathWest Laboratory } \\
\text { Medicine WA, } \\
\text { Nedlands, Australia }\end{array}$ & $\begin{array}{l}\text { Acquisition and analysis } \\
\text { of data }\end{array}$ \\
\hline $\begin{array}{l}\text { Rebecca Gooding, } \\
\text { PhD }\end{array}$ & $\begin{array}{l}\text { PathWest Laboratory } \\
\text { Medicine WA, } \\
\text { Nedlands, } \\
\text { Australia }\end{array}$ & $\begin{array}{l}\text { Acquisition and analysis } \\
\text { of data }\end{array}$ \\
\hline $\begin{array}{l}\text { Sarah A. } \\
\text { Sandaradura, } \\
\text { MBChB, FRACP, PhD }\end{array}$ & $\begin{array}{l}\text { The Children's } \\
\text { Hospital at } \\
\text { Westmead, New } \\
\text { South Wales, } \\
\text { Australia }\end{array}$ & $\begin{array}{l}\text { Acquisition and analysis } \\
\text { of data and drafting the } \\
\text { manuscript/figures for } \\
\text { intellectual content }\end{array}$ \\
\hline $\begin{array}{l}\text { Gina L. O'Grady, } \\
\text { MBChB, FRACP, PhD }\end{array}$ & $\begin{array}{l}\text { The Children's } \\
\text { Hospital at } \\
\text { Westmead, New } \\
\text { South Wales, } \\
\text { Australia }\end{array}$ & $\begin{array}{l}\text { Acquisition and analysis } \\
\text { of data }\end{array}$ \\
\hline $\begin{array}{l}\text { Michel C. Tchan, } \\
\text { MBBS, FRACP, PhD }\end{array}$ & $\begin{array}{l}\text { Westmead Hospital, } \\
\text { New South Wales, } \\
\text { Australia }\end{array}$ & $\begin{array}{l}\text { Acquisition and analysis } \\
\text { of data }\end{array}$ \\
\hline $\begin{array}{l}\text { David R. Mowat, } \\
\text { MBBS, FRACP }\end{array}$ & $\begin{array}{l}\text { Sydney Children's } \\
\text { Hospital, Randwick, } \\
\text { New South Wales, } \\
\text { Australia }\end{array}$ & $\begin{array}{l}\text { Acquisition and analysis } \\
\text { of data }\end{array}$ \\
\hline $\begin{array}{l}\text { Emily C. Oates, } \\
\text { MBBS, FRACP, PhD }\end{array}$ & $\begin{array}{l}\text { The Children's } \\
\text { Hospital at Westmead, } \\
\text { New South Wales, } \\
\text { Australia }\end{array}$ & $\begin{array}{l}\text { Acquisition and analysis } \\
\text { of data }\end{array}$ \\
\hline $\begin{array}{l}\text { Michelle A. Farrar, } \\
\text { MBBS, FRACP, PhD }\end{array}$ & $\begin{array}{l}\text { Sydney Children's } \\
\text { Hospital, Randwick, } \\
\text { New South Wales, } \\
\text { Australia }\end{array}$ & $\begin{array}{l}\text { Acquisition and analysis } \\
\text { of data }\end{array}$ \\
\hline
\end{tabular}


Appendix (continued)

\begin{tabular}{|c|c|c|}
\hline Name & Location & Contribution \\
\hline $\begin{array}{l}\text { Hugo Sampaio, } \\
\text { MBBCh, FRACP, } \\
\text { MPhil }\end{array}$ & $\begin{array}{l}\text { Sydney Children's } \\
\text { Hospital, Randwick, } \\
\text { New South Wales, } \\
\text { Australia }\end{array}$ & $\begin{array}{l}\text { Acquisition and analysis } \\
\text { of data }\end{array}$ \\
\hline $\begin{array}{l}\text { Alan Ma, MBBS, } \\
\text { FRACP }\end{array}$ & $\begin{array}{l}\text { The Children's } \\
\text { Hospital at Westmead, } \\
\text { New South Wales, } \\
\text { Australia }\end{array}$ & $\begin{array}{l}\text { Acquisition and analysis } \\
\text { of data }\end{array}$ \\
\hline $\begin{array}{l}\text { Katherine Neas, } \\
\text { MBChB, FRACP }\end{array}$ & $\begin{array}{l}\text { Genetic Health Service } \\
\text { NZ, Wellington, New } \\
\text { Zealand }\end{array}$ & $\begin{array}{l}\text { Acquisition and analysis } \\
\text { of data }\end{array}$ \\
\hline Min-Xia Wang, PhD & $\begin{array}{l}\text { Royal Prince Alfred } \\
\text { Hospital, } \\
\text { Camperdown, NSW, } \\
\text { Australia }\end{array}$ & $\begin{array}{l}\text { Acquisition and analysis } \\
\text { of data }\end{array}$ \\
\hline $\begin{array}{l}\text { Amanda Charlton, } \\
\text { MBChB, FRCPA }\end{array}$ & $\begin{array}{l}\text { The Children's } \\
\text { Hospital at } \\
\text { Westmead, New } \\
\text { South Wales, } \\
\text { Australia }\end{array}$ & $\begin{array}{l}\text { Acquisition and analysis } \\
\text { of data }\end{array}$ \\
\hline
\end{tabular}

\begin{tabular}{lll}
\hline $\begin{array}{l}\text { Charles Chan, MBBS } \\
\text { (Hons), FRCPA, PhD }\end{array}$ & $\begin{array}{l}\text { The Children's } \\
\text { Hospital at }\end{array}$ & $\begin{array}{l}\text { Acquisition and analysis } \\
\text { of data }\end{array}$ \\
& Westmead, New & \\
& South Wales, & \\
& Australia &
\end{tabular}

\begin{tabular}{lll}
\hline Diane N. Kenwright, & University of Otago, & $\begin{array}{l}\text { Acquisition and analysis } \\
\text { of data }\end{array}$ \\
MBBS, FRCPA & Wellington, New & Zealand
\end{tabular}

\begin{tabular}{lll}
\hline Nicole Graf, MBBS, & The Children's & $\begin{array}{l}\text { Acquisition and analysis } \\
\text { FRCPA }\end{array}$ \\
& Hospital at Westmead, & New South Wales, \\
& Australia & \\
&
\end{tabular}

\begin{tabular}{lll}
\hline Susan Arbuckle, & The Children's & $\begin{array}{l}\text { Acquisition and analysis } \\
\text { of data } \\
\text { MBBS, FRCPA }\end{array}$ \\
& Hospital at & \\
& Westmead, New & \\
& South Wales, & \\
& Australia &
\end{tabular}

\begin{tabular}{|c|c|c|}
\hline $\begin{array}{l}\text { Nigel F. Clarke, } \\
\text { MBChB, FRACP, PhD }\end{array}$ & $\begin{array}{l}\text { The Children's } \\
\text { Hospital at } \\
\text { Westmead, New } \\
\text { South Wales, } \\
\text { Australia }\end{array}$ & $\begin{array}{l}\text { Concept and design of } \\
\text { the study and } \\
\text { acquisition and } \\
\text { analysis of data }\end{array}$ \\
\hline $\begin{array}{l}\text { Daniel G. } \\
\text { MacArthur, PhD }\end{array}$ & $\begin{array}{l}\text { Broad Institute of MIT } \\
\text { \& Harvard, } \\
\text { Cambridge, MA }\end{array}$ & $\begin{array}{l}\text { Concept and design } \\
\text { of the study and } \\
\text { acquisition and } \\
\text { analysis of data }\end{array}$ \\
\hline $\begin{array}{l}\text { Kristi J. Jones, MBBS, } \\
\text { FRACP, PhD }\end{array}$ & $\begin{array}{l}\text { The Children's Hospital } \\
\text { at Westmead, New } \\
\text { South Wales, Australia }\end{array}$ & $\begin{array}{l}\text { Concept and design of } \\
\text { the study, acquisition } \\
\text { and analysis of data, } \\
\text { and drafting the } \\
\text { manuscript/figures } \\
\text { for intellectual } \\
\text { content }\end{array}$ \\
\hline Monkol Lek, PhD & $\begin{array}{l}\text { Broad Institute of MIT } \\
\text { \& Harvard, } \\
\text { Cambridge, MA }\end{array}$ & $\begin{array}{l}\text { Concept and design of } \\
\text { the study, acquisition } \\
\text { and analysis of data, } \\
\text { and drafting the } \\
\text { manuscript/figures } \\
\text { for intellectual } \\
\text { content }\end{array}$ \\
\hline
\end{tabular}

Appendix (continued)

\begin{tabular}{lll}
\hline Name & Location & Contribution \\
\hline $\begin{array}{l}\text { Sandra T. Cooper, } \\
\text { PhD }\end{array}$ & $\begin{array}{l}\text { The Children's } \\
\text { Hospital at } \\
\text { Westmead, New }\end{array}$ & $\begin{array}{l}\text { Concept and } \\
\text { design of the study, } \\
\text { acquisition and analysis } \\
\text { of data, and drafting the } \\
\text { South Wales, }\end{array}$ \\
Australia & $\begin{array}{l}\text { manuscript/figures } \\
\text { for intellectual } \\
\text { content }\end{array}$ \\
& \\
&
\end{tabular}

\section{References}

1. Moat SJ, Bradley DM, Salmon R, Clarke A, Hartley L. Newborn bloodspot screening for Duchenne muscular dystrophy: 21 years experience in Wales (UK). Eur J Hum Genet 2013;21:1049-1053.

2. Helderman-Van Den Enden ATJM, Madan K, Breuning MH, et al. An urgent need for a change in policy revealed by a study on prenatal testing for Duchenne muscular dystrophy. Eur J Hum Genet 2013;21:21-26.

3. Mendell JR, Shilling C, Leslie ND, et al. Evidence-based path to newborn screening for Duchenne muscular dystrophy. Ann Neurol 2012;71:304-313.

4. Emery AEH. The muscular dystrophies. Lancet 2002;359:687-695.

5. Flanigan KM. Duchenne and Becker muscular dystrophies. Neurol Clin 2014;32: 671-688.

6. Flanigan KM, Dunn DM, Von Niederhausern A, et al. Mutational spectrum of DMD mutations in dystrophinopathy patients: application of modern diagnostic techniques to a large cohort. Hum Mutat 2009;30:1657-1666

7. Bushby KMD, Gardner-Medwin D. The clinical, genetic and dystrophin characteristics of Becker muscular dystrophy: I. Natural history. J Neurol 1993;240:98-104.

8. Yazaki M, Yoshida K, Nakamura A, et al. Clinical characteristics of aged Becker muscular dystrophy patients with onset after 30 years. Eur Neurol 1999;42:145-149.

9. Heald A, Anderson LVB, Bushby KMD, Shaw PJ. Becker muscular dystrophy with onset after 60 years. Neurology 1994;44:2388-2390.

10. Bushby KMD, Cleghorn NJ, Curtis A, et al. Identification of a mutation in the promoter region of the dystrophin gene in a patient with atypical Becker muscular dystrophy. Hum Genet 1991;88:195-199.

11. Minetti C, Tanji K, Chang HW, et al. Dystrophinopathy in two young boys with exercise-induced cramps and myoglobinuria. Eur J Pediatr 1993;152:848-851.

12. Melis MA, Cau M, Muntoni F, et al. Elevation of serum creatine kinase as the only manifestation of an intragenic deletion of the dystrophin gene in three unrelated families. Eur J Paediatr Neurol 1998;2:255-261.

13. Muntoni F, Torelli S, Ferlini A. Dystrophin and mutations: one gene, several proteins, multiple phenotypes. Lancet Neurol 2003;2:731-740.

14. Ferlini A, Neri M, Gualandi F. The medical genetics of dystrophinopathies: molecular genetic diagnosis and its impact on clinical practice. Neuromuscul Disord 2013;23: 4-14.

15. Bladen CL, Salgado D, Monges S, et al. The TREAT-NMD DMD global database: analysis of more than 7,000 Duchenne muscular dystrophy mutations. Hum Mutat 2015;36:395-402.

16. Laing NG. Molecular genetics and genetic counselling for Duchenne/Becker muscular dystrophy. Mol Cel Biol Hum Dis Ser 1993;3:37-84.

17. Juan-Mateu J, Gonzalez-Quereda L, Rodriguez MJ, et al. DMD mutations in 576 dystrophinopathy families: a step forward in genotype-phenotype correlations. PLoS One 2015;10:e0135189.

18. Tuffery-Giraud S, Béroud C, Leturcq F, et al. Genotype-phenotype analysis in 2,405 patients with a dystrophinopathy using the UMD-DMD database: a model of nationwide knowledgebase. Hum Mutat 2009;30:934-945.

19. Jones HF, Bryen SJ, Waddell LB, et al. Importance of muscle biopsy to establish pathogenicity of DMD missense and splice variants. Neuromuscul Disord 2019;29: 913-919.

20. Cummings BB, Marshall JL, Tukiainen $\mathrm{T}$, et al. Improving genetic diagnosis in Mendelian disease with transcriptome sequencing. Sci Transl Med 2017;9:eaal5209.

21. Waddell LB, Tran J, Zheng XF, et al. A study of FHL1, BAG3, MATR3, PTRF and TCAP in Australian muscular dystrophy patients. Neuromuscul Disord 2011;21: 776-781.

22. Cooper ST, Lo HP, North KN. Single section Western blot: improving the molecular diagnosis of the muscular dystrophies. Neurology 2003;61:93-97.

23. Schneider CA, Rasband WS, Eliceiri KW. NIH Image to ImageJ: 25 years of image analysis. Nat Methods 2012;9:671-675.

24. Bryen SJ, Ewans L, Pinner J, et al. Recurrent TTN metatranscript-only c.39974$11 \mathrm{~T}>\mathrm{G}$ splice variant associated with autosomal recessive arthrogryposis multiplex congenita and myopathy. Hum Mutat 2020;41:403-411.

25. Bryen SJ, Joshi H, Evesson FJ, et al. Pathogenic abnormal splicing due to intronic deletions that induce biophysical space constraint for spliceosome assembly. Am J Hum Genet 2019;105:573-587. 
GTEx Consortium. The Genotype-Tissue Expression (GTEx) project. Nat Genet 2013;45:580-585.

27. Wimmer K, Schamschula E, Wernstedt A, et al. AG-exclusion zones revisited: lessons to learn from 91 intronic NF1 3' splice site mutations outside the canonical AGdinucleotides. Hum Mutat 2020;41:1145-1156.

28. Kim J, Hu C, El Achkar CM, et al. Patient-customized oligonucleotide therapy for a rare genetic disease. N Engl J Med 2019;381:1644-1652.
29. Muntoni F. Is a muscle biopsy in Duchenne dystrophy really necessary? Neurology 2001;57:574-575.

30. Hoffman EP, Kunkel LM, Angelini C, Clarke A, Johnson M, Harris JB. Improved diagnosis of Becker muscular dystrophy by dystrophin testing. Neurology 1989;39:1011-1017.

31. Van Den Bergen JC, Wokke BH, Janson AA, et al. Dystrophin levels and clinical severity in Becker muscular dystrophy patients. J Neurol Neurosurg Psychiatry 2014; $85: 747-753$. 


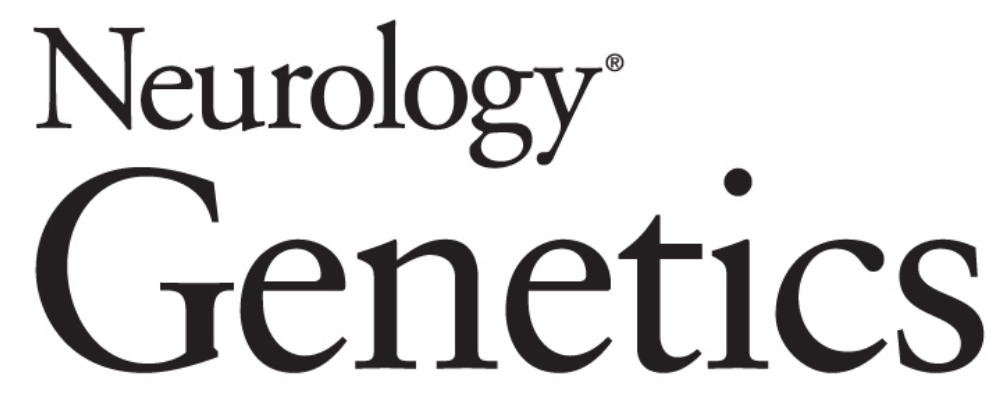

\section{WGS and RNA Studies Diagnose Noncoding DMD Variants in Males With High Creatine Kinase}

Leigh B. Waddell, Samantha J. Bryen, Beryl B. Cummings, et al. Neurol Genet 2021;7;

DOI 10.1212/NXG.0000000000000554

This information is current as of January 29, 2021

Neurol Genet is an official journal of the American Academy of Neurology. Published since April 2015, it is an open-access, online-only, continuous publication journal. Copyright Copyright $@ 2021$ The Author(s). Published by Wolters Kluwer Health, Inc. on behalf of the American Academy of Neurology.. All rights reserved. Online ISSN: 2376-7839.

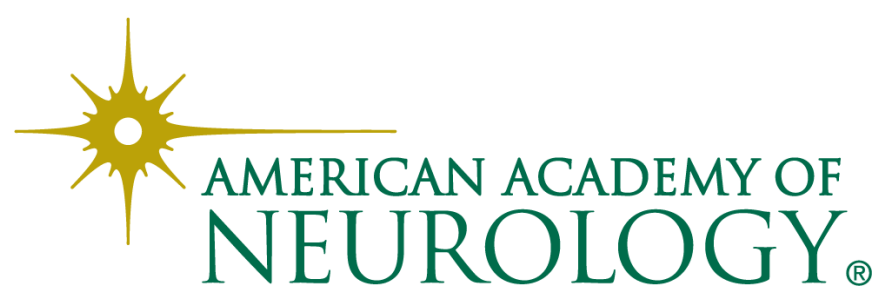




\section{Updated Information \& Services}

References

Citations

Subspecialty Collections

Permissions \& Licensing

Reprints including high resolution figures, can be found at: http://ng.neurology.org/content/7/1/e554.full.html

This article cites 31 articles, 2 of which you can access for free at: http://ng.neurology.org/content/7/1/e554.full.html\#\#ref-list-1

This article has been cited by 4 HighWire-hosted articles: http://ng.neurology.org/content/7/1/e554.full.html\#\#otherarticles

This article, along with others on similar topics, appears in the following collection(s):

All Clinical Neurology

http://ng.neurology.org//cgi/collection/all_clinical_neurology All Genetics http://ng.neurology.org//cgi/collection/all_genetics

\section{All Neuromuscular Disease}

http://ng.neurology.org//cgi/collection/all_neuromuscular_disease Diagnostic test assessment

http://ng.neurology.org//cgi/collection/diagnostic_test_assessment_ Muscle disease

http://ng.neurology.org//cgi/collection/muscle_disease

Information about reproducing this article in parts (figures,tables) or in its entirety can be found online at:

http://ng.neurology.org/misc/about.xhtml\#permissions

Information about ordering reprints can be found online:

http://ng.neurology.org/misc/addir.xhtml\#reprintsus

Neurol Genet is an official journal of the American Academy of Neurology. Published since April 2015, it is an open-access, online-only, continuous publication journal. Copyright Copyright $\odot 2021$ The Author(s). Published by Wolters Kluwer Health, Inc. on behalf of the American Academy of Neurology.. All rights reserved. Online ISSN: 2376-7839.

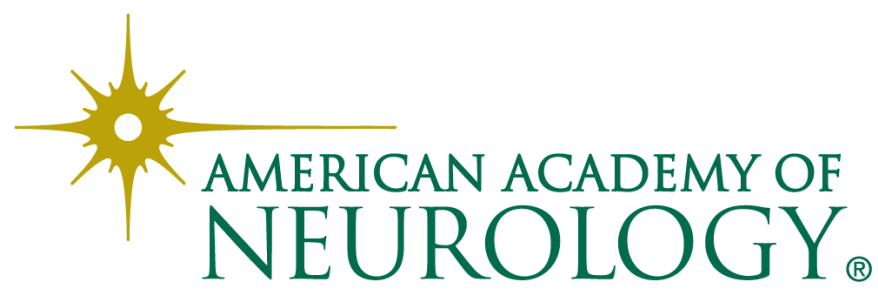

